\title{
Activation of human gingival epithelial cells by cell-surface components of black-pigmented bacteria: augmentation of production of interleukin-8, granulocyte colony-stimulating factor and granulocyte-macrophage colony-stimulating factor and expression of intercellular adhesion molecule 1
}

\author{
A. SUGIYAMA, A. UEHARA, K. IKI†, K. MATSUSHITA†, R. NAKAMURA*, T. OGAWA:, \\ S. SUGAWARA and H. TAKADA
}

Department of Microbiology and Immunology, Tohoku University School of Dentistry, Sendai 980-8575, * Department of Preventive Dentistry, University of Tokushima School of Dentistry, Tokushima 770-8504, $\dagger$ Departments of Biochemistry, Periodontology and Operative Dentistry and Endodontology, Kagoshima University Dental School, Kagoshima 890-8544 and \$Department of Oral Microbiology, Asahi University School of Dentistry, Gifu 501-0296, Japan

\begin{abstract}
Black-pigmented anaerobic bacteria, such as Porphyromonas gingivalis and Prevotella intermedia, are amongst the predominant bacteria in periodontal pockets and have been implicated in periodontal diseases. To elucidate the roles of gingival keratinocytes, which are the first cells encountered by oral bacteria in periodontal diseases, human gingival keratinocytes in primary culture were stimulated with cell-surface components of $P$. gingivalis and Pr. intermedia. A glycoprotein fraction from Pr. intermedia (PGP) clearly augmented the release of interleukin-8, granulocyte colony-stimulating factor and granulocyte-macrophage colony-stimulating factor, as determined by enzyme-linked immunosorbent assay. This PGP also induced expression of intercellular adhesion molecule-1 (ICAM-1), as determined by flow cytometry. The augmentation of mRNA expression for these molecules was also confirmed by reverse transcription PCR. In contrast, lipopolysaccharide (LPS) from Pr. intermedia and Escherichia coli was completely inactive in these assays. LPS fraction and purified fimbriae from $P$. gingivalis exhibited weak activities. Cytokine production and ICAM-1 expression by gingival keratinocytes might cause accumulation and activation of neutrophils in the epithelium and, therefore, may be involved in the initiation and development of inflammation in periodontal tissues.
\end{abstract}

Introduction

Adult periodontitis is a highly destructive chronic inflammatory disease. Oral black-pigmented anaerobic bacteria (BPB), such as Porphyromonas gingivalis and Prevotella intermedia, are amongst the predominant bacteria in periodontal pockets of patients with periodontitis and have been implicated in periodontal diseases $[1,2]$. Possible virulence factors of $\mathrm{BPB}$ in

Received 9 Jan. 2001; revised version received 30 May 2001; accepted 20 June 2001.

Corresponding author: Professor H. Takada (e-mail: dent-ht @mail.cc.thoku.ac.jp). relation to the pathogenesis of periodontal diseases have been reviewed $[3,4]$ and the immunobiological activities of cell-surface components, such as lipopolysaccharide (LPS) and fimbriae have been investigated. LPS from BPB has been reported to exhibit unique bioactivities that differ from those of common LPS prepared from Enterobacteriaceae, such as Escherichia coli and Salmonella spp. [5,6]. Immunocompetent cells from animals and human peripheral blood cells were used in the initial studies, and subsequently human fibroblasts derived from periodontal tissues were examined. In a previous study, a novel bioactive glycoprotein fraction, designated as Prevotella glycoprotein (PGP), was isolated from $\mathrm{Pr}$. 
intermedia ATCC 25611 by the hot phenol-water extraction method [7]. PGP has been shown to stimulate lymphoid cells from genetically LPS-resistant mice and human gingival fibroblasts to secrete inflammatory cytokines, whereas purified LPS prepared from the bacterium with phenol-chloroform-petroleum ether (PCP) mixture was devoid of such activities. Therefore, it has been proposed that the unique bioactivities of BPB LPS reported to date may be attributable to PGP or PGP-like material(s) co-existing with the BPB LPS extracted by the phenol-water extraction method.

The first cells encountered by bacteria are epithelial cells, and the predominant cell type in the gingival epithelium is the keratinocyte [8]. Skin keratinocytes and keratinocytic cell lines produce various cytokines and growth factors [9] and some studies [10,11] have also shown cytokine production by human oral keratinocytes and related cell lines in response to stimulation with oral bacteria. However, the cytokine repertoire of gingival keratinocytes in response to specific oral bacterial component(s) is not clear at present.

The aim of the present study was to elucidate the possible involvement of gingival keratinocytes in the host response to bacterial stimuli. The cytokine response and expression of an adhesion molecule by human gingival keratinocytes in primary culture after stimulation with various cell-surface components of BPB was examined in relation to the initiation and establishment of periodontal disease.

\section{Materials and methods}

\section{Bacterial components and cytokines}

PGP was prepared from Pr. intermedia ATCC 25611 as described previously [7]. Briefly, lyophilised bacterial cells were extracted twice with phenol-water at $67^{\circ} \mathrm{C}$ for $20 \mathrm{~min}$. The pooled extract in the water phase was dialysed against distilled water and ultracentrifuged at $140000 \mathrm{~g}$ for $3 \mathrm{~h}$ to remove LPS as a sediment. The supernate was lyophilised and a portion was dissolved in sodium deoxycholate $0.2 \%-100 \mathrm{~mm}$ Tris- $5 \mathrm{mM}$ sodium EDTA ( $\mathrm{pH}$ 8.5) which was then subjected to chromatography on Sephadex G 100 (Pharmacia, Uppsala, Sweden) and eluted with the same buffer. The fraction lacking Limulus activity but showing a strong mitogenic effect on splenocytes from both $\mathrm{C} 3 \mathrm{H} / \mathrm{HeN}$ and $\mathrm{C} 3 \mathrm{H} / \mathrm{HeJ}$ was treated further with NP1 nuclease (Yamasa, Choshi, Japan) and re-chromatographed on Sephadex G 100 to prepare the final fraction, PGP. LPS was extracted from same bacteria with a PCP mixture according to the method of Galanos et al. [12] before further treatment with NP1 nuclease and pronase E from Streptomyces griseus attached to carboxymethyl cellulose beads (Sigma). The purified LPS was mitogenic on splenocytes from $\mathrm{C} 3 \mathrm{H} / \mathrm{HeN}$ but not those from $\mathrm{C} 3 \mathrm{H} / \mathrm{HeJ}$ mice [7]. Fimbriae were isolated from $P$. gingivalis 381 and purified as described previously [13]. LPS could not be extracted from P. gingivalis 381 by the PCP method. Therefore, an LPS fraction was prepared from $P$. gingivalis 381 by the conventional hot phenol-water extraction method [7]. Ultrapurified LPS from Salmonella choleraesuis subsp. choleraesuis Abortus-equi [14] was a gift from C. Galanos (Max Plank Institut für Immunbiologie, Freiburg, Germany). Human natural interferon (IFN)- $\gamma$ (antiviral activity, $8.0 \times 10^{6} \mathrm{IU} / \mathrm{mg}$ of protein) was provided by Hayashibara Bioscience Institute (Okayama, Japan) and rHuIL-1 $\alpha$ (lymphocyte activating activity, $2.3 \times 10^{7}$ $\mathrm{U} / \mathrm{mg}$ of protein) was supplied by Dainippon Pharmaceutical (Osaka, Japan).

\section{Cells and cell culture}

Human gingival epithelial cells were prepared from the explants of normal human gingival tissues of 7-10 year-old donors with their own and their parents' informed consent. The explants were cut into pieces and cultured in tissue culture dishes $100 \mathrm{~mm}$ in diameter (Falcon; Becton Dickinson Labware, Lincoln Park, NJ, USA) in keratinocyte serum-free medium (Gibco BRL, Grand Island, NY, USA) containing bovine pituitary extract $0.05 \% \mathrm{v} / \mathrm{w}$ and human epidermal growth factor 1-51 (recombinant from $E$. coli, $820 \mu \mathrm{M}$ ) supplemented with kanamycin (Meiji Seiyaku, Tokyo, Japan) $200 \mu \mathrm{g} / \mathrm{ml}$ with a medium change every 4 days for 15-20 days until subconfluent cell monolayers were formed. Human gingival keratinocytes obtained in this manner were characterised as keratinocytes on the basis of immunostaining with anticytokeratin type I and II antibodies (AE1+AE3 mouse IgG1 MAb; Progen Biotechnik GmbH, Germany) [15]. The cells were also confirmed to be devoid of CD14, a receptor for LPS and various bacterial cell-surface components by flow cytometry and reverse transcription PCR (RT-PCR) (data not shown). The cells were used within three passages.

\section{Flow cytometry}

Flow cytometric analyses were performed with a fluorescence-activated cell sorter (FACS) (FACScan; Becton Dickinson, Mountain View, CA, USA). For immunofluorescent staining, confluent human gingival keratinocytes in six-well plates (Falcon) at a density of $5 \times 10^{5}$ cells $/ 3 \mathrm{ml} /$ well were incubated with or without various test materials for $48 \mathrm{~h}$, then cells were collected by trypsinisation and washed in PBS. The cells were stained with anti-CD54 (intercellular adhesion molecule-1, ICAM-1) monoclonal antibody (MAb) directly conjugated with phycoerythrin (PE) (mouse IgG2b, obtained from Becton Dickinson) at $4{ }^{\circ} \mathrm{C}$ for $30 \mathrm{~min}$. Murine IgG2b (Coulter, Miami, FL, USA) was used as a control isotype-matched antibody to exclude the possibility of non-specific binding of the anti-CD54 MAb. To calculate the percentage of positive cells, the baseline cursor was set at a channel that yielded $<2 \%$ 
of the events positive with a second antibody control. Fluorescence to the right was counted as specific binding.

\section{Enzyme-linked immunosorbent assay (ELISA)}

For the detection of cytokines in the human gingival keratinocyte culture supernate, the confluent cells $\left(2.4 \times 10^{4} / 200 \mu \mathrm{l} /\right.$ well) in 96 -well plates (Falcon) were incubated with or without various test materials for 24-72 h. Cultures were performed in triplicate and the concentrations of cytokines in the supernates were determined with ELISA kits for interleukin (IL)- $1 \alpha$, IL-1 $\beta$, IL-2, IL-6, IL-8, IL-15, tumour necrosis factor (TNF)- $\alpha$, and granulocyte-macrophage colony-stimulating factor (GM-CSF) (Biosource, Camarillo, CA, USA) and granulocyte colony-stimulating factor (G-CSF) (Japan Immunoresearch Lab. Co. Ltd, Takasaki, Japan).

\section{$R T-P C R$}

Total cellular RNA was extracted from cells with Isogen (Nippon Gene, Tokyo, Japan) according to the manufacturer's instructions. Reverse transcription of RNA samples to cDNA was performed with Moloney murine leukaemia virus reverse transcriptase (Gibco $\mathrm{BRL}$ ) and oligo(dT) $)_{12-18}$ primer (Gibco BRL). To transcribe total RNA into cDNA, $2.5 \mu \mathrm{g}$ of RNA, $0.25 \mu \mathrm{g}$ oligo(dT) $)_{12-18}$ primer, $500 \mathrm{U}$ of Moloney murine leukaemia virus reverse transcriptase, $10 \mu \mathrm{l}$ of $5 \times$ first strand buffer, $0.2 \mathrm{mM}$ deoxynucleoside triphosphates (dNTPs) and $10 \mathrm{mM}$ dithiothreitol (DTT) were added to a total volume of $50 \mu \mathrm{l}$. The reaction mixture was incubated for $1 \mathrm{~h}$ at $37^{\circ} \mathrm{C}$ followed by $5 \mathrm{~min}$ at $95^{\circ} \mathrm{C}$. The primers used for PCR had the following sequences: IL-8, forward 5'-GATTGAGAGTGGACCA CACT-3' and reverse 5'-TCTCCCGTGCAATATCT AGG-3'; ICAM-1, forward 5'-ACCATGGAGCCAAT TTCTCG-3' and reverse 5'-GAGAAGGAGTCGTTG CCATA-3'; G-CSF, forward 5'-CTGCTTGAGCCA ACTCCATA-3' and reverse 5'-GGAGTCAAACC ATGTCCCAA-3'; GM-CSF, forward 5'-GTAGAGAC ACTGCTGCTGAG-3' and reverse 5'-CCTGTATCA GGGTCAGTGTG-3'; and human glyceraldehyde-3phosphate dehydrogenase (GAPDH) forward 5'TGAAGGTCGGAGTCAACGGATTTGGT-3' and reverse 5'-CATGTGGGCCATGAGGTCCACCAC-3'. The primers for IL-8, ICAM-1, G-CSF, GM-CSF and GAPDH were constructed to generate fragments of 422, 276, 871, 456 and $983 \mathrm{bp}$, respectively. The PCR mixture contained $5 \mu \mathrm{l}$ of the cDNA mixture, $2 \mu \mathrm{l}$ of $10 \times$ PCR buffer, $0.2 \mathrm{mM}$ dNTPs, 50 pmol of each primer and $0.1 \mu$ l of Ex taq DNA polymerase (Takara, Tokyo, Japan) in a total volume of $20 \mu \mathrm{l}$. Amplification was performed in a model MP TP3000 PCR thermal cycler (Takara) as follows: 25 cycles of denaturation at $94^{\circ} \mathrm{C}$ for $1 \mathrm{~min}$, annealing at $63^{\circ} \mathrm{C}$ for IL-8, at $65^{\circ} \mathrm{C}$ for ICAM-1, at $65.7^{\circ} \mathrm{C}$ for G-CSF, at $66.7^{\circ} \mathrm{C}$ for GM-CSF and at $60^{\circ} \mathrm{C}$ for $\mathrm{GAPDH}$, for $1 \mathrm{~min}$; extension at $72^{\circ} \mathrm{C}$ for $1 \mathrm{~min}$ and final extension at $72^{\circ} \mathrm{C}$ for $3 \mathrm{~min}$.
Amplified samples were visualised on agarose $2.0 \%$ gels stained with ethidium bromide and photographed under UV illumination. The bands on the photographs were scanned and then analysed with Image Master 1D (Pharmacia Biotech, Uppsala, Sweden). Results were expressed as relative mRNA accumulation corrected with GAPDH mRNA as an internal standard.

\section{Miscellaneous}

Most experiments were performed more than three times and representative results are presented. In cytokine assays, based on the mean value and SD, the statistical significance of differences between each test and the respective control was examined by a oneway analysis of variance (ANOVA) by the Bonferroni or Dunn method; $p$ values $<0.05$ were considered significant.

\section{Results}

Cytokine induction by BPB cellular components in human gingival keratinocytes

The time-course of IL- 8 secretion by human gingival keratinocytes in response to the PGP fraction from $P r$. intermedia was examined (Fig. 1). The PGP fraction $(10 \mu \mathrm{g} / \mathrm{ml})$ induced IL-8 secretion from 24 to $72 \mathrm{~h}$ at a similar level; therefore, cultivation for cytokine production was done for $24 \mathrm{~h}$ in the following experiments. The PGP fraction enhanced secretion of IL-8,

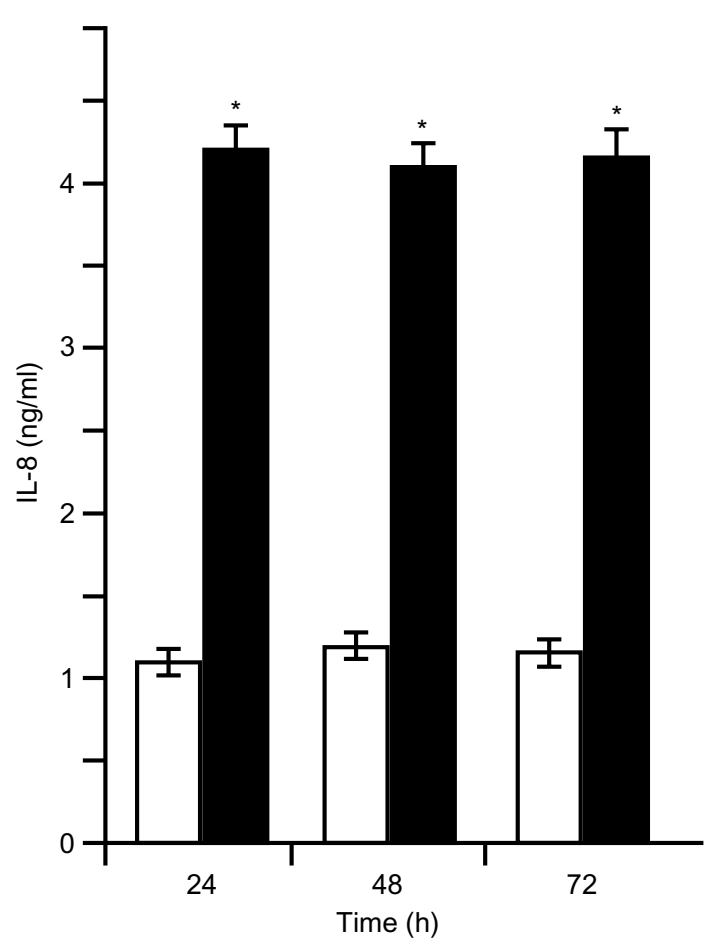

Fig. 1. IL-8 secretion by human gingival keratinocytes stimulated with the PGP fraction from Pr. intermedia. Primary cultures of human gingival keratinocytes were incubated with PGP $(10 \mu \mathrm{g} / \mathrm{ml}$; $\square)$ or medium alone ( $\square)$ for $24-72 \mathrm{~h}$ $\left({ }^{*} \mathrm{p}<0.01\right)$. 
G-CSF and GM-CSF in a dose-dependent manner and the maximum levels induced by PGP $10 \mu \mathrm{g} / \mathrm{ml}$ were similar to or higher than respective levels of cytokines induced by rHuIL-1 $\alpha$ and HuIFN- $\gamma$ (Fig. 2). Three LPS specimens were almost inactive in this respect, except that $P$. gingivalis LPS significantly induced G-CSF production when the highest concentration $(10 \mu \mathrm{g} / \mathrm{ml})$ was used. The purified fimbriae of $P$. gingivalis at $100 \mu \mathrm{g} / \mathrm{ml}$ significantly induced IL- 8 and G-CSF. The supernates of the keratinocyte cultures did not contain detectable levels of IL-2, IL-6, IL-15 and TNF- $\alpha$. IL$1 \alpha$ and IL- $\beta$ were detected but were not upregulated by the bacterial components tested (data not shown).

\section{Effect of BPB cell-surface components on ICAM-1 expression by human gingival keratinocytes}

HuIFN- $\gamma$ induced ICAM-1 expression on almost $100 \%$ of gingival keratinocytes (Fig. 3). Among the bacterial cell-surface components, Pr. intermedia PGP $(10 \mu \mathrm{g} / \mathrm{ml})$ and $P$. gingivalis LPS $(10 \mu \mathrm{g} / \mathrm{ml})$ augmented ICAM-1 expression, from c. 5\% in medium alone to c. 50 and $30 \%$, respectively. P. gingivalis fimbriae $(100 \mu \mathrm{g} / \mathrm{ml})$ exhibited weak activity $(12.5 \%)$ whereas purified LPS $(10 \mu \mathrm{g} / \mathrm{ml})$ from $P r$. intermedia lacked activity like Salmonella LPS (data not shown).

mRNA expression for IL-8, G-CSF, GM-CSF and ICAM-1 by gingival keratinocytes stimulated with $B P B$ cell-surface components

To assess the specific induction of these molecules at the mRNA level, RT-PCR was performed with the RNA isolated from gingival keratinocytes. First, the time-course of IL- 8 mRNA expression induced by the
PGP fraction $(10 \mu \mathrm{g} / \mathrm{ml})$ was assessed. The peak expression was observed after stimulation for $8 \mathrm{~h}$ (Fig. 4); therefore, RT-PCR was performed after cultivation for $8 \mathrm{~h}$ in the following experiments. Subsequently, the expression of various cytokines and adhesion molecules was examined. The levels of IL-8, G-CSF, GM-CSF and ICAM-1 mRNAs from cells treated with Pr. intermedia PGP, P. gingivalis fimbriae and $P$. gingivalis LPS were increased as compared with those from untreated control cells (Figs. 5 and 6). In contrast, the cytokine and ICAM-1 mRNAs were scarcely detected in cells stimulated with Pr. intermedia LPS or were detected at intensities similar to those in medium alone (control) by RT-PCR (Fig. 5).

\section{Discussion}

BPB, in particular $P$. gingivalis and $P r$. intermedia, possess various virulence factors on their cell surfaces, such as LPS $[5,6]$ and fimbriae $[16,17]$. The immunobiological activities of these factors have been studied extensively in relation to the pathogenesis of periodontal diseases. The present study has demonstrated that Pr. intermedia PGP fraction stimulated gingival keratinocytes to increase production of IL-8, G-CSF and GM-CSF and augmented expression of ICAM-1. In contrast, LPS from Pr. intermedia as well as Salmonella completely lacked these activities. These results are not surprising because gingival keratinocytes do not have CD14, the main receptor for LPS [18] on cell-surface. In this study, exogenous soluble CD14 was not added because serum-free medium was used throughout the experiments. However, it must be noted that human gingival keratinocytes in primary culture

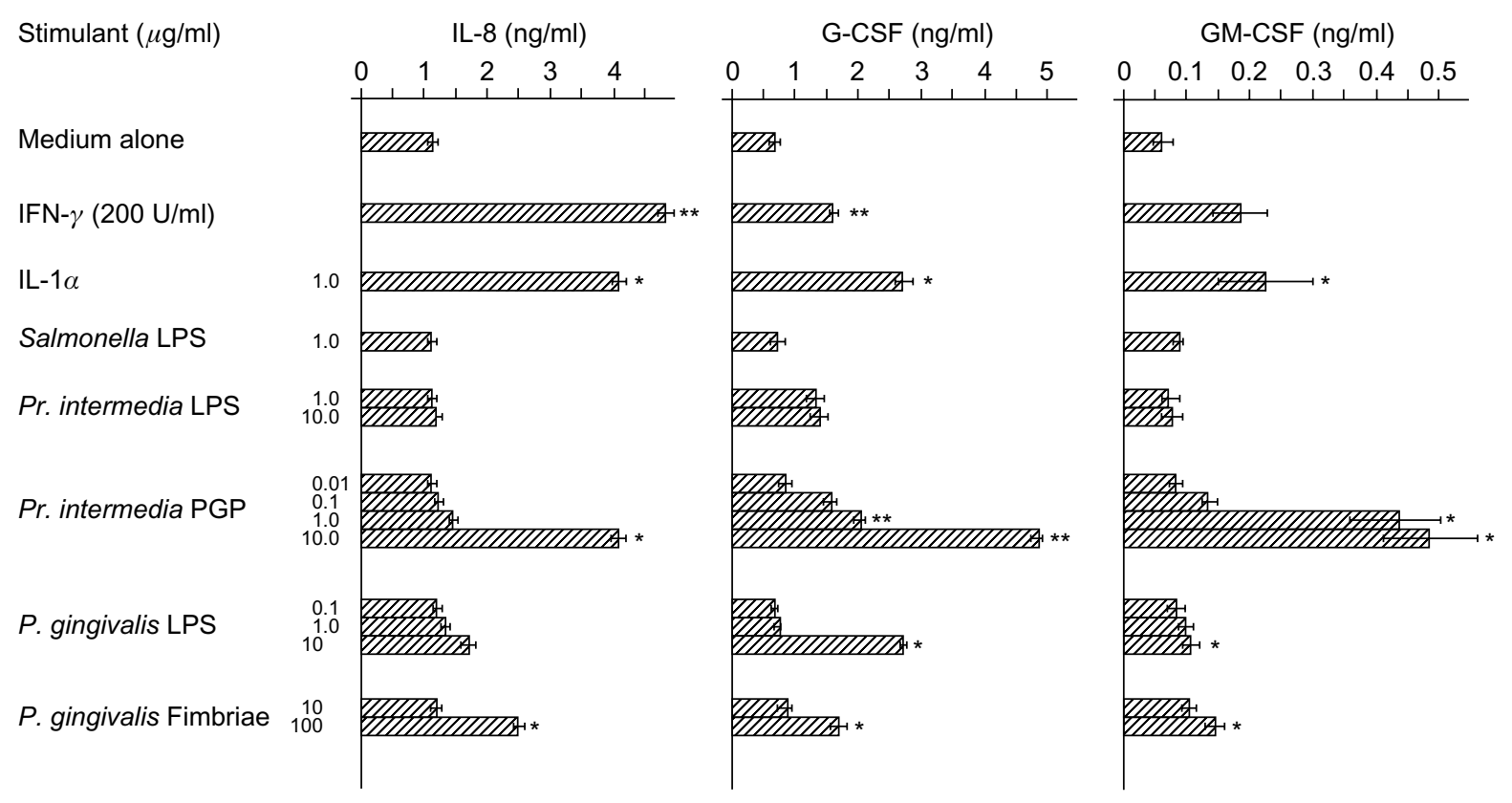

Fig. 2. Cytokine secretion by human gingival keratinocytes stimulated with cell-surface components from Pr. intermedia and $P$. gingivalis. Primary cultures of human gingival keratinocytes were incubated with stimulant or medium alone for $24 \mathrm{~h}\left({ }^{*} \mathrm{p}<0.05\right.$, $* * \mathrm{p}<0.01)$ 

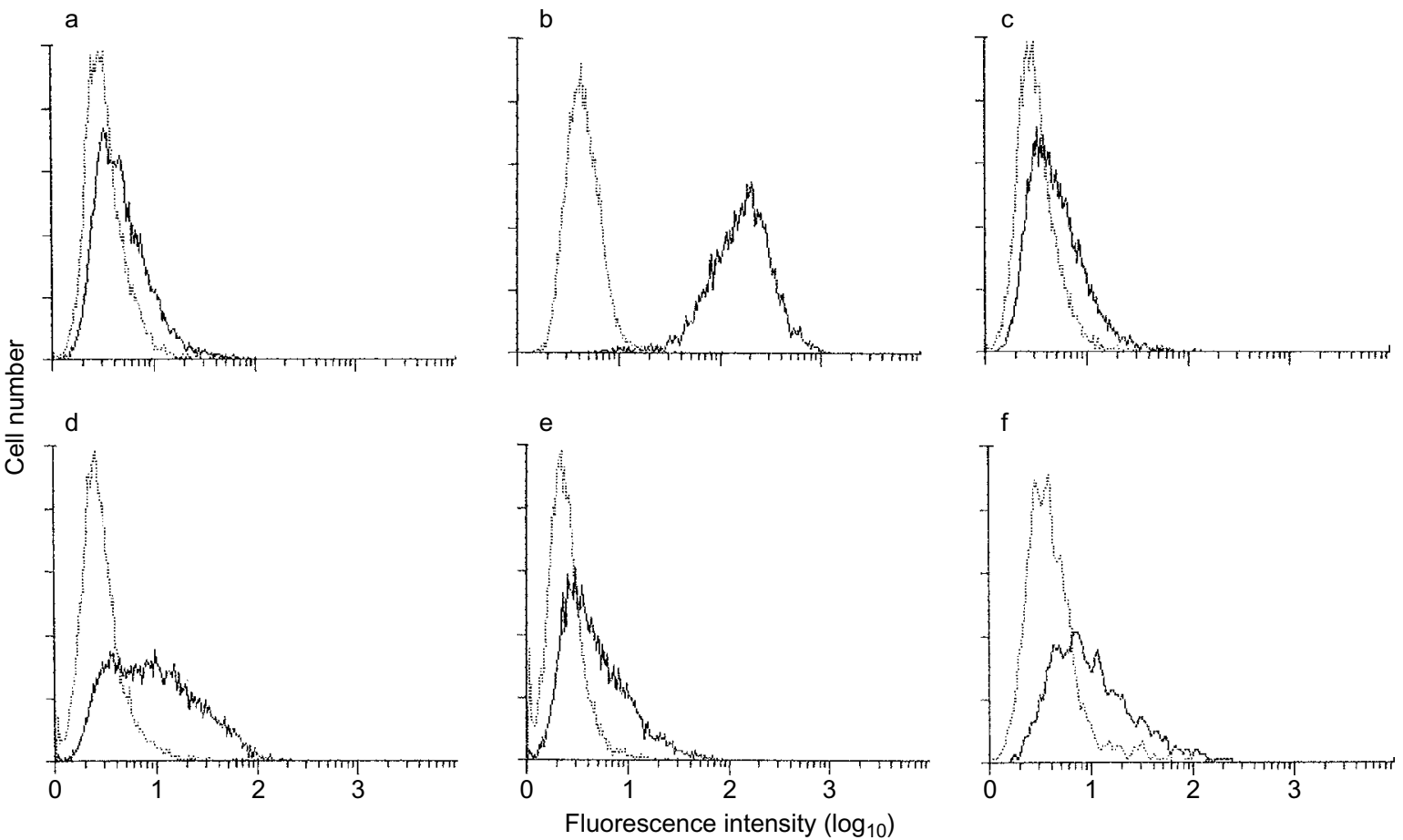

Fig. 3. ICAM-1 expression on human gingival keratinocytes stimulated with various cell-surface components of BPB. Human gingival keratinocytes were incubated with stimulant or medium alone for $48 \mathrm{~h}$ : a, medium alone $(4.9 \%)$; b, IFN- $\gamma(98.7 \%)$; c, Salmonella LPS (5.1\%); d, Pr. intermedia PGP (49.0\%); e, P. gingivalis fimbriae (12.5\%); f, P. gingivalis LPS (30.5\%).

a
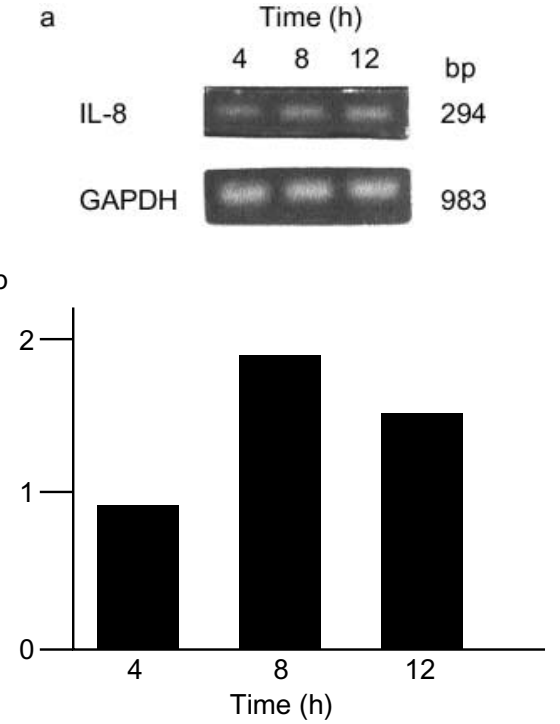

Fig. 4. The time-course of mRNA expression by human gingival keratinocytes after stimulation with PGP fractions from $P r$. intermedia. Human gingival keratinocytes were cultured with or without test material $(10 \mu \mathrm{g} / \mathrm{ml})$ for $4-12 \mathrm{~h}$. PCR products were electrophoresed on agarose $2 \%$ gels and visualised by staining with ethidium bromide (a). Blots were further quantified with an imaging analyser and results are expressed as relative mRNA accumulation corrected relative to GAPDH mRNA as an internal standard (b).

and oral epithelial cell lines do not respond to LPS even in the presence of soluble CD14 [19]. It has also been reported that the primary culture and cell line culture in experiments [19] involving low and high (physiological) concentrations of calcium, respectively, indicate that calcium concentration does not influence the responses of epithelial cells to LPS. Therefore, the observed activities of $P$. gingivalis LPS might be attributable to PGP or PGP-like material possibly present in the LPS fraction. In this context, previous research has shown that a synthetic compound mimicking $P$. gingivalis lipid A, unlike the natural counterpart, did not activate macrophages from $\mathrm{C} 3 \mathrm{H} / \mathrm{HeJ}$ mice [20].

P. gingivalis and Pr. intermedia are capable of invading human gingival epithelial cells and oral epithelial cell lines $[21,22]$. P. gingivalis fimbriae may be involved in invasion of the bacteria into the epithelium, because a fimbriae-deficient mutant of $P$. gingivalis was less invasive than the parent strain, and the presence of fimbriae receptor on gingival epithelial cells has been suggested $[23,24]$. Gingival epithelial cells invaded by $P$. gingivalis show reduced production of IL-8 in response to other bacterial stimuli [25]. Although binding of $P$. gingivalis fimbriae on gingival keratinocytes has been suggested by several investigators $[23,26]$, the present report appears to be the first study to show that $P$. gingivalis fimbriae activated human gingival keratinocytes to enhance production of IL-8. This finding is not in conflict with the above inhibitory effect of fimbriate $P$. gingivalis cells on cytokine production by the gingival keratinocytes [25], because the latter report only indicated fimbriae-dependent invasion of the bacterium and did not show that fimbriae themselves inhibited the function of gingival epithelial cells. 


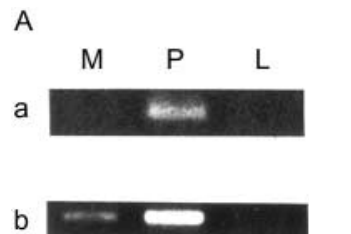

b

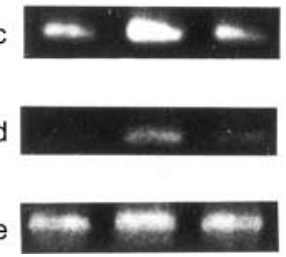

B
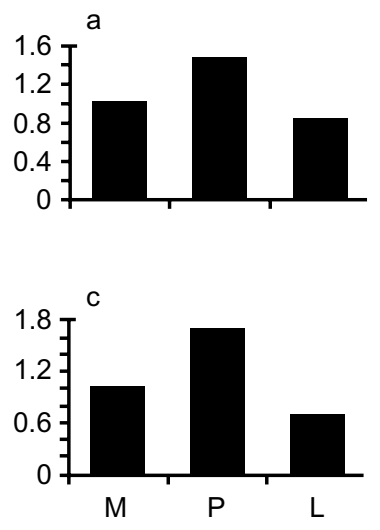
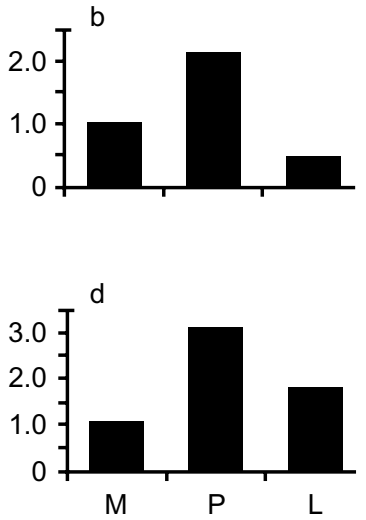

Fig. 5. Induction of mRNA expression by human gingival keratinocytes after stimulation with PGP and LPS fractions from Pr. intermedia. Human gingival keratinocytes were cultured with or without test materials for $8 \mathrm{~h}$. PCR products were electrophoresed on agarose $2 \%$ gels and visualised by staining with ethidium bromide (A). Blots were further quantified with an imaging analyser and results are expressed as relative mRNA accumulation corrected relative to GAPDH mRNA as an internal standard (B). M, medium alone; P, PGP; L, LPS; a, IL-8; b, G-CSF; c, GM-CSF; d, ICAM-1; e, GAPDH.

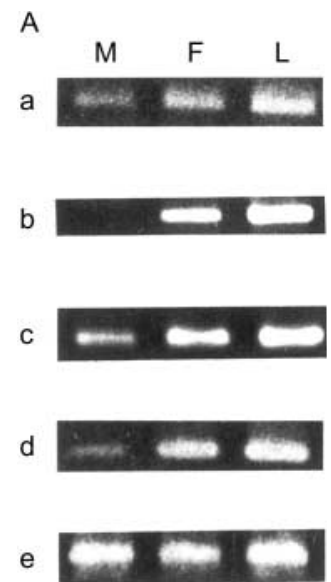

B
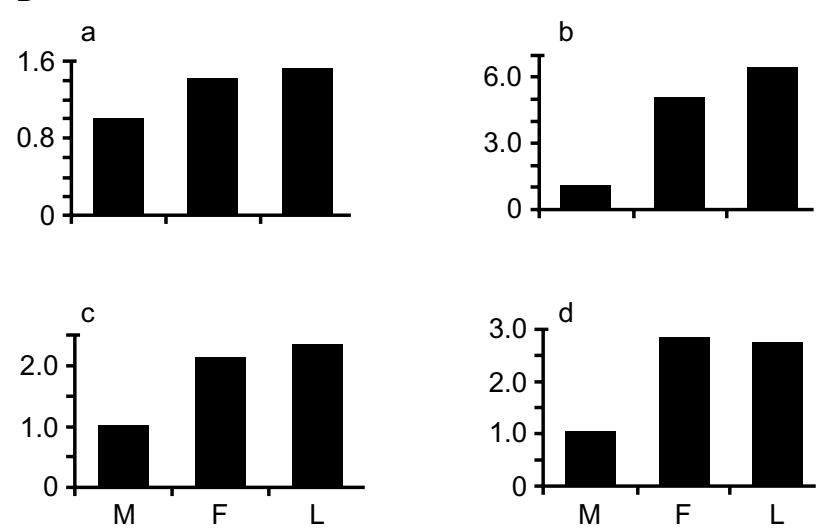

Fig. 6. Induction of mRNA expression by human gingival keratinocytes after stimulation with fimbriae and LPS fractions from $P$. gingivalis. Human gingival keratinocytes were cultured with or without test materials for $8 \mathrm{~h}$. PCR products were electrophoresed on agarose $2 \%$ gels and visualised by staining with ethidium bromide (A). Blots were further quantified with an imaging analyser and results are expressed as relative mRNA accumulation corrected relative to GAPDH mRNA as an internal standard (B). M, medium alone; F, fimbriae; L, LPS; a, IL-8; b, G-CSF; c, GM-CSF; d, ICAM-1; e, GAPDH.

As mentioned above, many previous studies demonstrated that skin keratinocytes produced various cytokines and growth factors and expressed adhesion molecules on their surface as a result of stimulation with environmental stimuli such as UV light, and were thought to actively participate in inflammatory and immunological responses [27]. However, until recently, gingival keratinocytes have been thought to act as a mechanical barrier against exogenous stimuli. The production of inflammatory cytokine by gingival keratinocytes in response to bacterial stimuli was examined here. Unexpectedly, most cytokines were not detected or were not upregulated by bacterial stimuli. The results presented here demonstrate in a primary cell culture system that human gingival keratinocytes secrete IL-8, G-CSF and GM-CSF and express ICAM-1 after stimulation with cell-surface components from BPB. In the inflamed gingiva, IL-8 has been detected mainly in the epithelial layer [28]. IL-8 secreted by gingival epithelial cells might act as a chemo-attractant for neutrophils and T cells $[29,30]$. These accumulated cells might express LFA-1 on their cell surface and attach to epithelial cells via ICAM-1 and LFA-1 interaction, then infiltrate into the gingival epithelium [8,27]. In fact, ICAM-1 and IL-8 mRNA expression are topographically associated with the area of neutrophil migration in the junctional epithelium [31]. IL-8-activated neutrophils show a respiratory burst to produce superoxide [30]. G-CSF and GMCSF are also capable of activating neutrophils to augment superoxide anion generation in response to the bacterial chemo-attractant $N$-folmylmethionyl-leucylphenylalanine (FMLP) [32,33]. These responses of neutrophils might in turn injure gingival epithelial cells [34] and might result in the initiation and establishment of periodontal diseases. 
We thank Mr T. Kuroishi (T-cell Research Institute, Sendai) and Dr M. Takahashi (Tohoku University School of Dentistry) for analysis of RT-PCR by the Image Master 1D and cytokine assays, respectively. We also thank Mr D. Mrozek (Medical English Service, Kyoto, Japan) for reviewing this paper. This work was supported in part by Grants-in-Aid for Scientific Research (09671843 and 10470378) from the Ministry of Education, Science, Sports, and Culture of Japan, and Grants-in-Aid for Scientific Research (12470380 and 13671894) from Japan Society for the Promotion of Science. A.S. (Tohoku University) was supported from April 1996 to March 1998 by research fellowships of the Japan Society for the Promotion of Young Scientists.

\section{References}

1. Socransky SS, Haffajee AD. The bacterial etiology of destructive periodontal disease: current concepts. J Periodontol 1992; 63 (4 Suppl): 322-331.

2. Zambon JJ, Grossi S, Dunford R, Haraszthy VI, Preus H, Genco RJ. Epidemiology of subgingival bacterial pathogens in periodontal disease. In: Genco RJ, Hamada S, Lehner T, McGhee J, Mergenhagen S (eds) Molecular pathogenesis of periodontal disease. Washington, DC, ASM Press. 1994: 3-12.

3. Lamont RJ, Jenkinson HF. Life below the gum line: pathogenic mechanisms of Porphyromonas gingivalis. Microbiol Mol Biol Rev 1998; 62: 1244-1263.

4. Holt SC, Kesavalu L, Walker S, Genco AC. Virulence factors of Porphyromonas gingivalis. Periodontology 2000 1999; 20: $168-238$.

5. Hamada S, Takada H, Ogawa T, Fujiwara T, Mihara J. Lipopolysaccharides of oral anaerobes associated with chronic inflammation: chemical and immunomodulating properties. Int Rev Immunol 1990; 6: 247-261.

6. Wilson M. Biological activities of lipopolysaccharide and endotoxin. In: Shah HN, Mayrand D, Genco RJ (eds) Biology of the species Porphyromonas gingivalis. Boca Raton, FL, CRC Press. 1993: 171-197.

7. Iki K, Kawahara $\mathrm{K}$, Sawamura $\mathrm{S}$ et al. A novel component different from endotoxin extracted from Prevotella intermedia ATCC 25611 activates lymphoid cells from $\mathrm{C} 3 \mathrm{H} / \mathrm{HeJ}$ mice and gingival fibroblasts from humans. Infect Immun 1997; 65: 4531-4538.

8. Suchett-Kaye G, Morrier J-J, Barsotti O. Interactions between non-immune host cells and the immune system during periodontal disease: role of the gingival keratinocyte. Crit Rev Oral Biol Med 1998; 9: 292-305.

9. Feliciani C, Gupta AK, Sauder DN. Keratinocytes and cytokine/growth factors. Crit Rev Oral Biol Med 1996; 7: 300-318.

10. Huang GT-J, Haake SK, Kim J-W, Park N-H. Differential expression of interleukin-8 and intercellular adhesion molecule-1 by human gingival epithelial cells in response to Actinobacillus actinomycetemcomitans or Porphyromonas gingivalis infection. Oral Microbiol Immunol 1998; 13: 301-309.

11. Yumoto $H$, Nakae $H$, Fujinaka $K$, Ebisu $S$, Matsuo $T$. Interleukin-6 (IL-6) and IL-8 are induced in human oral epithelial cells in response to exposure to periodontophathic Eikenella corrodens. Infect Immun 1999; 67: 384-394.

12. Galanos C, Lüderitz $\mathrm{O}$, Westphal $\mathrm{O}$. A new method for the extraction of R lipopolysaccharides. Eur J Biochem 1969; 9: $245-249$.

13. Ogawa T, Shimauchi H, Hamada S. Mucosal and systemic immune responses in BALB/c mice to Bacteroides gingivalis fimbriae administered orally. Infect Immun 1989; 57: 3466-3471.

14. Galanos C, Lüderitz O, Westphal O. Preparation and properties of a standardized lipopolysaccharide from Salmonella abortus equi (Novo-Pyrexal). Zentralbl Bakteriol Orig A 1979; 243 : $226-244$.
15. Sugiyama A, Arakaki R, Ohnishi T, Arakaki N, Daikuhara Y, Takada H. Lipoteichoic acid and interleukin 1 stimulate synergistically production of hepatocyte growth factor (scatter factor) in human gingival fibroblasts in culture. Infect Immun 1996; 64: 1426-1431.

16. Genco RJ, Sojar H, Lee J-Y, Sharma A, Bedi G, Cho M-I, Dyer DW. Porphyromonas gingivalis fimbriae: structure, function, and insertional inactivation mutants. In: Genco RJ, Hamada S, Lehner T, McGhee J, Mergenhagen S (eds) Molecular pathogenesis of periodontal disease. Washington, DC, ASM Press. 1994: 13-23.

17. Hamada S, Fujiwara T, Morishima S et al. Molecular and immunological characterization of the fimbriae of Porphyromonas gingivalis. Microbiol Immunol 1994; 38: 921-930.

18. Ulevitch RJ, Tobias PS. Receptor-dependent mechanisms of cell stimulation by bacterial endotoxin. Anпu Rev Immunol 1995; 13: 437-457.

19. Uehara A, Sugawara S, Tamai R, Takada H. Contrasting responses of human gingival and colonic epithelial cells to lipopolysaccharides, lipoteichoic acids and peptidoglycans in the presence of soluble CD14. Med Microbiol Immunol 2001; 189: $185-192$.

20. Ogawa $\mathrm{T}$, Asai $\mathrm{Y}$, Yamamoto $\mathrm{H}$ et al. Immunobiological activities of a chemically synthesized lipid A of Porphyromonas gingivalis. FEMS Immunol Med Microbiol 2000; 28: $273-281$.

21. Lamont RJ, Chan A, Belton CM, Izutsu KT, Vasel D, Weinberg A. Porphyromonas gingivalis invasion of gingival epithelial cells. Infect Immun 1995; 63: 3878-3885.

22. Dorn BR, Leung K-P, Progulske-Fox A. Invasion of human oral epithelial cells by Prevotella intermedia. Infect Immun 1998; 66: 6054-6057.

23. Du L, Pellen-Mussi P, Chandad F, Mouton C, Bonnaure-Mallet M. Fimbriae and the hemagglutinating adhesin HA-Ag2 mediate adhesion of Porphyromonas gingivalis to epithelial cells. Infect Immun 1997; 65: 3875-3881.

24. Weinberg A, Belton CM, Park Y, Lamont RJ. Role of fimbriae in Porphyromonas gingivalis invasion of gingival epithelial cells. Infect Immun 1997; 65: 313-316.

25. Darveau RP, Belton CM, Reife RA, Lamont RJ. Local chemokine paralysis, a novel pathogenic mechanism for Porphyromonas gingivalis. Infect Immun 1998; 66: 1660-1665.

26. Njoroge T, Genco RJ, Sojar HT, Hamada N, Genco CA. A role for fimbriae in Porphyromonas gingivalis invasion of oral epithelial cells. Infect Immun 1997; 65: 1980-1984.

27. Barker JNWN, Mitra RS, Griffiths CEM, Dixit VM, Nickoloff BJ. Keratinocytes as initiators of inflammation. Lancet 1991; 337: $211-214$.

28. Fitzgerald JE, Kreutzer DL. Localization of interleukin-8 in human gingival tissues. Oral Microbiol Immunol 1995; 10: 297-303.

29. Larsen CG, Anderson AO, Appella E, Oppenheim JJ, Matsushima K. The neutrophil-activating protein (NAP-1) is also chemotactic for $\mathrm{T}$ lymphocytes. Science 1989; 243: 1464-1466.

30. Oppenheim JJ, Zachariae COC, Mukaida N, Matsushima K. Properties of the novel proinflammatory supergene "intercrine" cytokine family. Annu Rev Immunol 1991; 9: 617-648.

31. Tonetti MS, Imboden MA, Lang NP. Neutrophil migration into the gingival sulcus is associated with transepithelial gradients of interleukin-8 and ICAM-1. $J$ Periodontol 1998; 69: $1139-1147$.

32. Weisbart RH, Golde DW, Clark SC, Wong GG, Gasson JC. Human granulocyte-macrophage colony-stimulating factor is a neutrophil activator. Nature $1985 ; 314$ : 361-363.

33. Balazovich KJ, Almeida HI, Boxer LA. Recombinant human G-CSF and GM-CSF prime human neutrophils for superoxide production through different signal transduction mechanisms. J Lab Clin Med 1991; 118: 576-584.

34. Altman LC, Baker C, Fleckman P, Luchtel D, Oda D. Neutrophil-mediated damage to human gingival epithelial cells. J Periodont Res 1992; 27: 70-79. 